\title{
Exploring the Blended Teaching Mode under the Guidance of OBE Theory-Taking the Course of English Newspaper Reading I in Zhejiang Yuexiu University as an Example
}

\author{
Fang Jin \\ Network Communication College, Zhejiang Yuexiu University, Shaoxing, China \\ Email: 20042008@zyufl.edu.cn
}

How to cite this paper: Jin, F. (2021). Exploring the Blended Teaching Mode under the Guidance of OBE Theory-Taking the Course of English Newspaper Reading I in Zhejiang Yuexiu University as an Example. Open Journal of Modern Linguistics, 11, 511-519.

https://doi.org/10.4236/ojml.2021.114038

Received: June 8, 2021

Accepted: July 10, 2021

Published: July 13, 2021

Copyright $\odot 2021$ by author(s) and Scientific Research Publishing Inc. This work is licensed under the Creative Commons Attribution International License (CC BY 4.0).

http://creativecommons.org/licenses/by/4.0/

\begin{abstract}
With the comprehensive promotion of education informatization, blended teaching has led learners' learning to deep learning, personalized learning and lifelong learning by combining new teaching and traditional teaching in an "online" + "offline" way. Based on OBE (Outcome-based Education) theory, this paper analyzes the three main processes of teaching design of English Newspaper Reading course: before, during and after class, and analyzes and adjusts the problems in practice to provide countermeasures for the continuous development of blended teaching.
\end{abstract}

\section{Keywords}

Outcome Based Education, Blended Teaching Model, Teaching Process, Strategies

\section{Introduction}

Teaching reform objectives and tasks. The English Newspaper Reading I is the course guided by OBE (Outcome-based Education) theory, insists on studentcentered and result-oriented, closely combines with the school's own characteristics and professional talent training program, and builds an ecosystem with blended teaching as the core.

This reform is based on the principle of continuous improvement, taking the construction of the course "English Newspaper Reading 1" as the anchor and breakthrough point to improve the quality of teaching and learning, taking students as the center, strengthening the hybrid course design, technical support, 
resource construction, quality evaluation and other aspects, and continuously improving the hybrid teaching mode to achieve higher goals of education training and output (Alka, Prasoom, \& Samo, 2019; Jachin, N. \& Usagawa, T., 2017; Huang, Zhou, \& Wang, 2006). The teaching design follows the classical model of Lorin W. Anderson's competencies, highlighting the progressive thinking process of memorization, understanding, application, analysis, evaluation and creation, progressively analyzing the cultural connotations through the introduction of basic professional knowledge, focusing on cultivating students' thinking and discernment skills and intercultural communication skills, and reflecting the goal of training applied talents (Nitzke, Tardel, \& Hansen, 2019; Smith \& Hill, 2019).

\section{Online and Offline Hybrid Teaching Mode of English Newspaper Reading I}

The course is organized through a mixture of online learning and face-to-face interactive machines, linking before, during and after class, linking low and high level tasks, shallow and deep constructive learning. As the builders and practitioners of the teaching model, teachers should keep pace with the times and flexibly use advanced "Internet+" technologies as aids and enablers for classroom teaching activities, conduct circular experiments in teaching practice, and enhance the effectiveness of blended teaching in the "Internett" era (Ahmed \& Tayseer, 2017; Alipour \& Ehmke, 2020; Lin \& Pan, 2016). This will enhance the effectiveness of blended teaching in the Internet era and promote the healthy development of other ESP courses.

\subsection{Analysis of the Learning Situation}

Under the leadership of the "Foreign Language+" strategy of Zhejiang Yuexiu College of Foreign Languages, this course is dedicated to cultivating complex applied talents with international vision and competitiveness. The course is designed for third-year students majoring in journalism (including international journalism), communication, network and new media, editing and publishing, and digital media technology (Song, 2020; Wang, Chen, \& Tai, 2021.; Jin, 2021). We analyse the three aspects of knowledge, ability and environmental adaptability of the students who take the course.

Professional knowledge: Students have gone through the prerequisite course "News Interviewing and Reporting" and have a certain level of familiarity with Chinese news and related contents. English knowledge: most of the students have passed the fourth level of English (CET4), and a few have passed the level sixth (CET6), so they have a relatively good foundation in English (Bruggeman, Tondeur, \& Struyven, 2021; You, 2020). Before studying the set content, it is important to understand the students' level of interest in the course (Yen \& Lee, 2011). According to the questionnaire survey we know that students are particularly interested in the differences between Chinese and Western news reporting 
and are more motivated to study.

Analysis of students' learning ability: Through the study of journalism and communication courses in freshman and sophomore years, students have a rich reserve of relevant professional knowledge (Malczyk, 2019). After two years of listening, speaking, reading and writing in English, students have improved their ability in all aspects and are fully capable of completing the learning tasks before this section.

Analysis of students' adaptability to the information-based learning environment: as the course is open to junior students, many of the foundation courses in the previous two years have adopted blended teaching methods, and students have fully adapted to the online and offline learning mode, therefore, the conditions for flipped classroom teaching are available (Wang, 2018).

\subsection{Teaching Process Design}

The teaching process runs through "before-during-after": before the lesson, students complete online micro-video learning, micro-lesson learning, online micro-test (pre-test and post-test). During the lesson, the teacher will analyze doubts and teach key knowledge, and after the lesson, students will work in small groups to write news reports, features and reviews. The content of each session progresses from low to high levels of difficulty (Huang, Zhou, \& Wang, 2006). The final result is the internalisation of students' knowledge and the development of their independent learning and teamwork skills.

1) Pre-course preparation and online independent learning. For the first teaching preparation, teachers first build the course and set up the basic information of the course, and post the syllabus and teaching plan to the platform, while informing students to register, log in to the platform, join the course by scanning the QR code and understand the basic information of the course (Jiang \& Deng, 2019). During this process, teachers should have in-depth communication and exchange with students and listen to their opinions extensively, which is conducive to both teaching design and students experiencing a sense of presence and stimulating learning autonomy.

2) Offline classroom implementation. The teacher designs guiding questions to test the effect of online learning before class, and collects information on students' online learning problems, summarizes and refines them, and determines the content of classroom implementation, and for students' common problems, the teacher explains them uniformly in class. For the key points in the teaching, the classroom group discussion is adopted to discuss and report, and finally the teacher will make comments and summaries to reveal mistakes, affirm achievements, encourage poor students and motivate advanced ones, and students will reflect and correct mistakes according to the evaluation feedback (Zhou, 2018). The above training will promote internalization of knowledge and improvement of skills.

3) Post-class online development. Teachers test the effectiveness of the on- 
line and offline hybrid teaching mode based on the completion of students' online assignments and tests and their knowledge mastery, and then reflect on the problems that exist, and continuously improve and optimize the teaching program in the subsequent practical teaching to further enhance the subsequent teaching effect. Teachers can also set up comprehensive and application-oriented training projects based on students' results in the offline classroom, and release them to students in the form of videos through the SPOC platform to help students digest and understand the knowledge of the course itself, improve their comprehensive abilities outside the classroom and achieve the transfer of knowledge.

4) Course assessment aspects. The assessment phase of the course focuses on completing the OBE theory of how to know that students have achieved the learning outcomes. The course "English News Reading 1" is based on the OBE theory and uses a variety of assessment methods to effectively evaluate students' learning in a blended teaching mode (Fu \& Shang, 2021). In the implementation of this teaching model, each student's learning process is evaluated in three parts: the usual performance grade, the individual grade and the final result evaluation.

The regular grades include pre-class tests, class discussions, and individual reports. Individual grades include group confrontation, group assignments and individual assignments, among which group confrontation and group assignments are evaluated by the teacher, students' mutual evaluation and contribution. The final evaluation includes exam results, teacher's evaluation of students' performance in the whole teaching, and team evaluation. The whole evaluation system takes into account the degree of achievement of the course objectives in all aspects, as well as the students' learning ability and cooperation ability. Therefore, the final grade is composed of the components of the usual assessment. For each link, the corresponding weighting should be paid attention to when setting up, and the linear weighting synthesis should be made according to different proportions to establish an effective comprehensive evaluation mechanism. Based on the feedback from students in each chapter, we will further adjust the content of the post-learning and revise the implementation plan of the hybrid teaching mode. This is a cycle of promotion, so that teaching and learning can grow together.

Students who took the course were assessed in January 2020, and the distribution of grades in the experimental and control classes is below in Table 1.

Statistical analysis of students' overall assessment scores is summarized below in Figure 1.

\subsection{Teaching Method Strategies}

In the hybrid teaching model based on OBE theory of flipped classroom teaching, a combination of task-driven teaching, guided teaching, collaborative inquiry and other methods are used for teaching, thus effectively ensuring teaching 
Table 1. The distribution of grades in the experimental and control classes.

\begin{tabular}{|c|c|c|c|c|c|c|c|c|c|}
\hline Grade Point Range & $0-39$ & $40-49$ & $50-59$ & $60-69$ & $70-79$ & $80-89$ & $90-100$ & Subtotal & Average \\
\hline Total & 1 & 4 & 2 & 205 & 263 & 112 & 8 & 596 & 72.5 \\
\hline $\begin{array}{l}\text { Editing and Publishing } \\
1801 \text { (Experimental) }\end{array}$ & 1 & 2 & 0 & 16 & 29 & 1 & 0 & 49 & 69.7 \\
\hline $\begin{array}{l}\text { Editing and Publishing } \\
1802 \text { (Experimental) }\end{array}$ & 0 & 0 & 0 & 21 & 23 & 3 & 0 & 47 & 71 \\
\hline $\begin{array}{l}\text { Web and New Media } \\
1801 \text { (control) }\end{array}$ & 0 & 0 & 0 & 21 & 20 & 7 & 0 & 48 & 71.3 \\
\hline $\begin{array}{l}\text { Web and New Media } \\
1801 \text { (control) }\end{array}$ & 0 & 0 & 1 & 11 & 23 & 11 & 1 & 47 & 74.1 \\
\hline $\begin{array}{l}\text { Communication } 1801 \\
\text { (experimental) }\end{array}$ & 0 & 0 & 0 & 12 & 18 & 8 & 0 & 38 & 72.9 \\
\hline $\begin{array}{l}\text { Communication } 1802 \\
\text { (experimental) }\end{array}$ & 0 & 0 & 0 & 8 & 18 & 14 & 0 & 40 & 75.4 \\
\hline $\begin{array}{l}\text { Communication } 1803 \\
\text { (experimental) }\end{array}$ & 0 & 0 & 1 & 6 & 17 & 11 & 3 & 39 & 74.1 \\
\hline $\begin{array}{l}\text { Communication } 1804 \\
\text { (control) }\end{array}$ & 0 & 0 & 0 & 12 & 14 & 14 & 1 & 41 & 75.3 \\
\hline $\begin{array}{l}\text { Communication } 1805 \\
\text { (control) }\end{array}$ & 0 & 1 & 0 & 25 & 16 & 5 & 0 & 47 & 68.8 \\
\hline $\begin{array}{l}\text { Communication } 1806 \\
\text { (control) }\end{array}$ & 0 & 0 & 0 & 22 & 16 & 6 & 0 & 44 & 70.1 \\
\hline $\begin{array}{l}\text { Journalism } 1801 \\
\text { (control) }\end{array}$ & 0 & 0 & 0 & 20 & 17 & 7 & 0 & 44 & 71.5 \\
\hline $\begin{array}{l}\text { Journalism } 1802 \\
\text { (control) }\end{array}$ & 0 & 1 & 0 & 20 & 13 & 5 & 3 & 42 & 70.6 \\
\hline $\begin{array}{l}\text { Journalism } 1803 \\
\text { (Experimental) }\end{array}$ & 0 & 0 & 0 & 7 & 21 & 13 & 0 & 41 & 75.1 \\
\hline $\begin{array}{l}\text { Journalism } 1804 \\
\text { (Experimental) }\end{array}$ & 0 & 0 & 0 & 4 & 18 & 7 & 0 & 29 & 75.7 \\
\hline $\begin{array}{l}\text { Digital Media } \\
\text { Technology } 1801 \\
\text { (control) }\end{array}$ & 0 & 0 & 0 & 4 & 14 & 0 & 0 & 18 & 61.1 \\
\hline $\begin{array}{l}\text { Digital Media } \\
\text { Technology } 1802 \\
\text { (Experimental) }\end{array}$ & 0 & 0 & 0 & 20 & 1 & 1 & 0 & 22 & 69.8 \\
\hline
\end{tabular}

quality (Liu, Wan, \& Yuan, 2016).

Task-driven teaching. Students' learning tasks before and after class are carried out in the form of practical application-oriented cases to stimulate students' interest and enhance their sense of achievement.

Guided teaching. The whole teaching process realizes teacher-led and student-centered teaching. Teachers guide students to conduct independent learning before class, teachers guide students to learn new knowledge, teachers guide 


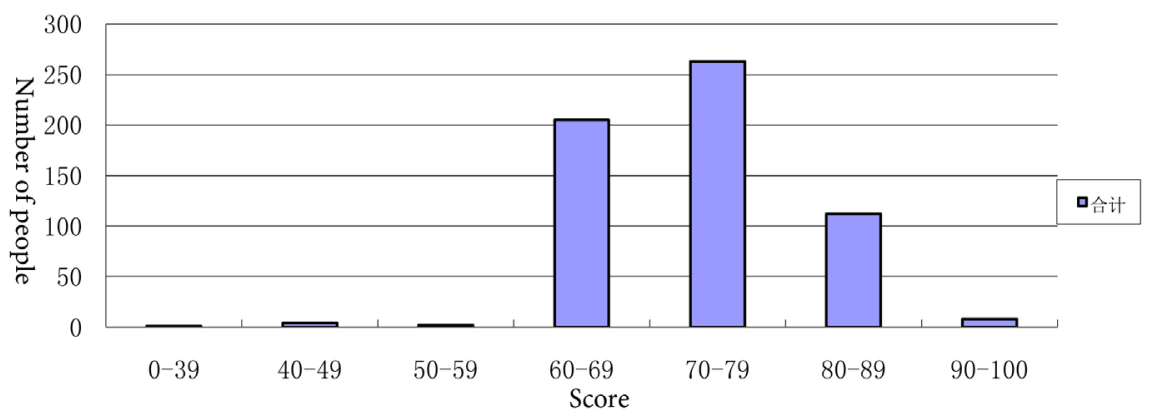

Figure 1. Course grade distribution chart.

students to conduct collaborative inquiry, and teachers always maintain the interaction between teachers and students offline and online, and teachers help students solve problems (Li, Zhu, Liu, \& Xia, 2014).

Collaborative inquiry. Students work in groups to develop their assignments, and we collaborate to discuss the implementation plan and divide the work to complete the learning tasks, forming a positive interactive learning atmosphere.

\subsection{Teaching Evaluation}

Through the implementation of the online and offline hybrid teaching mode, students reflect seriously on the shortcomings according to the course evaluation report generated by the Wisdom Tree platform system, strive to improve their learning attitude and methods, and actively participate in the next study (Huang, 2020). The evaluation of the teaching process includes student evaluation and teacher self-evaluation. Students evaluate the teaching content, methods, objectives, teaching progress and task difficulty and make suggestions and comments, while teachers reflect on the evaluation of students and form teaching improvement opinions to guide the next teaching. In this way, the cycle is promoted in order to achieve mutual growth in teaching and learning.

\subsection{Course Construction Highlights and Expected Achievements}

\subsubsection{Innovation and Entrepreneurship Integration}

This course places special emphasis on cultivating students' ability to master reporting, feature writing, and news commentary in newspaper English. In addition, the course aims to cultivate students' newspaper reading ability to design the knowledge lecture of newspaper theory and combine it with students' majors, and to guide the English newspaper reading course from the theoretical level to the practical level through the students' professional advantages.

\subsubsection{Cultivate Students' Entrepreneurial and Innovative Qualities through the Linkage of Teaching and Industry}

The class introduces examples of newspaper articles from life and interacts with students so that they can understand the main features of newspapers and the similarities and differences between Chinese and Western reporting through reflection. During the construction of this course, students will present their 
learning experience or learning outcomes through the online platform.

\subsubsection{Sustainable Teaching and Learning}

Thinking about the teaching and learning process from the teacher's point of view, and making adjustments to improve deficiencies.

\section{Problems and Suggestions}

In the actual teaching process, the following problems were encountered due to the differences in teachers' teaching abilities and levels as well as students' inability to adapt to the new environment and new teaching methods and means (Yen \& Lee, 2011).

Teachers' teaching level: The difference of teachers' teaching ability is not reflected in their familiarity with knowledge points, but in how to effectively organize teaching language, vividly explain teaching cases, effectively organize classroom activities and ask valuable questions in order to realize the role of a guide in the face of a large number of learners (Alka, Prasoom, \& Samo, 2019). In response to such shortcomings, our curriculum team immediately set up a group of teachers, mainly supervisors, to help team members sharpen their lessons by listening to lessons, teaching and research and other exchanges, using collective lesson preparation programs to share quality resources, and sparing no effort to create golden lessons.

Students' motivation and concentration in learning: Students' independent learning ability is evident in the link that requires them to accept a task sheet to watch a teacher-made lesson or video and complete the homework assigned by the teacher before class. At present, students generally do not have enough initiative and motivation to learn, and often start the first month of the school year with full energy and the second three months lazily, which is a challenge to the problem of how to mobilize students' motivation. In response to such problems, our college was led by the Office of Academic Affairs to carry out exchanges with student representatives, giving us valuable advice from the student level, including how to design task sheets, how to design courseware, and control the length of videos at a few minutes, all of which are the topics of most interest to students. After we collected valuable feedback, we promptly adjusted our next steps and did our best to capture the students' enthusiasm online and offline (Wang, Chen, \& Tai, 2021).

Teaching environment: Online and offline hybrid teaching is characterized by the completion of the internalization of knowledge in the classroom. In addition to the independent completion of tasks by students, there is an important part of the internalization process, which requires that the number of students should not be too large, and in the actual teaching environment of this course, the number of students in a class is mostly above 70 . To address these issues, we try to develop the use of online learning time before and after class, assigning group collaboration online in advance to give students sufficient time to prepare for the best teaching. 


\section{Summary}

Our English Newspaper Reading 1 course uses the Wisdom Tree plus Moso teach platform for teaching. Teachers upload teaching resources including PowerPoint and their own recorded teaching videos made by themselves or collected online to the online platform, and then release the corresponding selfstudy tasks and learning schedule. Students can master the main points and difficulties of the practical training operation in advance by watching the teaching videos, and they can also watch them repeatedly if they don't understand them, saving a lot of offline time. The platform provides a class group chat function, which is convenient for teachers and students to use it to exchange and discuss. Students will give online feedback on their learning problems, and the teacher team will give timely online tutorials, and students can also exchange their gains and feelings with each other.

SPOC online courses take advantage of online information technology to extend the learning space from the classroom to outside the classroom, moving from shallow learning to deep learning, enabling students to continuously identify, think about and solve problems in the course of their per-course knowledge base.

\section{Acknowledgements}

This paper is an achievement of 2019 online and offline hybrid teaching and learning reform at Zhejiang Yuexiu University-exploring the online and offline hybrid teaching model of English Newspaper Reading I based on OBE theory (No. JGH1911).

\section{Conflicts of Interest}

The author declares no conflicts of interest regarding the publication of this paper.

\section{References}

Ahmed, N., \& Tayseer, A. (2017). The Effect of Designing a Blended Learning Environment on Achievement and Deep Learning of Graduate Students at the Arabian Gulf University. Open Journal of Social Sciences, 5, 248-260.

Alipour, P., \& Ehmke, T. (2020). A Comparative Study of Online vs. Blended Learning on Vocabulary Development among Intermediate EFL Learners. Cogent Education, 7, Article ID: 1857489. https://doi.org/10.1080/2331186X.2020.1857489

Alka, D., Prasoom, D., \& Samo (2019). Factors Affecting Students' Engagement with Online Content in Blended Learning. Kybernetes, 48, 1500-1515. https://doi.org/10.1108/K-10-2018-0559

Bruggeman, B., Tondeur, J., \& Struyven, K. (2021). Experts Speaking: Crucial Teacher Attributes for Implementing Blended Learning in Higher Education. The Internet and Higher Education, 48, Article ID: 100772. https://doi.org/10.1016/j.iheduc.2020.100772

Fu, L. Y., \& Shang, F. F. (2021). Cultivating Innovative Talents in Journalism and Communication Practice in Universities Based on OBE Concept-An Example of Teaching Reform of Online and Offline Hybrid First-Class Courses. Cuanbo Yu Banqua, No. 1.

Huang, G. N. (2020). Exploring the Concept and Method of MOOC Teaching by Com- 
bining Online and Offline. Software Guide, 19, No. 12.

Huang, R. H., Zhou, Y. L., \& Wang, Y. (2006). The Theory and Practice of Blended Learning. Beijing: Higher Education Press.

Jachin, N., \& Usagawa, T. (2017). Potential Impact of Blended Learning on Teacher Education in Mongolia. Creative Education, 8, 1481-1494.

Jiang, L. L., \& Deng, J. (2019). Research on Hybrid Teaching in Applied Undergraduate Institutions in "Internet+" Environment. Education Modernization, No. 54.

Jin, X. (2021). Correlation Analysis, Optimization and Computer Simulation of Teaching Efficiency and Blended Learning of Higher Vocational English Based on POA and CoI Algorithm. Journal of Physics: Conference Series, 1865, Article ID: 042050. https://doi.org/10.1088/1742-6596/1865/4/042050

Li, Z. Y., Zhu, H., Liu, Z. J., \& Xia, Y. J. (2014). Guiding the Reform of Higher Engineering Education with Result-Oriented Educational Ideas. Research in Higher Education of Engineering, No. 2, 29-35.

Lin, X. Y., \& Pan, J. S. (2016). Design and Implementation of Blended Teaching Model Based on Flipped Classroom. China Vocational and Technical Education, No. 2.

Liu, R., Wan, L., \& Yuan, F. (2016). A Study on the Evaluation of College Course Learning from the Perspective of OBE Theory. China Light Industry Education, No. 1.

Malczyk, B. R. (2019). Introducing Social Work to HyFlex Blended Learning: A StudentCentered Approach. Journal of Teaching in Social Work, 39, 414-428. https://doi.org/10.1080/08841233.2019.1652226

Nitzke, J., Tardel, A., \& Hansen, S. S. (2019). Training the Modern Translator-The Acquisition of Digital Competencies through Blended Learning. The Interpreter and Translator Trainer, 13, 292-306. https://doi.org/10.1080/1750399X.2019.1656410

Smith, K., \& Hill, J. (2019). Defining the Nature of Blended Learning through Its Depiction in Current Research. Higher Education Research \& Development, 38, 383-397. https://doi.org/10.1080/07294360.2018.1517732

Song, C. Z. (2020). Research on Blended Learning Implementation. Journal of Physics: Conference Series, 1682, Article ID: 012086. https://doi.org/10.1088/1742-6596/1682/1/012086

Wang, J. H. (2018). Knowledge Transformation in Teacher Education Internship: Connotation and Characteristics. Journal of Hainan Normal University (Social Science Edition), No. 3.

Wang, N., Chen, J. W., \& Tai, M. (2021). Blended Learning for Chinese University EFL Learners: Learning Environment and Learner Perceptions. Computer Assisted Language Learning, 34, 297-323. https://doi.org/10.1080/09588221.2019.1607881

Yen, J. C., \& Lee, C. Y. (2011). Exploring Problem Solving Patterns and Their Impact on Learning Achievement in a Blended Learning Environment. Computers \& Education, 56, 138-145. https://doi.org/10.1016/j.compedu.2010.08.012

You, Y. H. (2020). On Teaching Reform of Online and Offline Mixed Flipped Classroom of Sports Statistics Based on the Concept of "Outcome-Based Education". Journal of Luoyang Normal University, 39, No. 5.

Zhou, J. Y. (2018). Research on the Design and Application of Blended Teaching Based on the Intelligent Teaching Platform "Rain Classroom". Digital Technology and Application, No. 12. 